Portland State University

PDXScholar

1973

\title{
Increasing Visual Sensitivity in Urban School \\ Students: a Strategy for Involving Students in Aesthetic Concerns
}

Harold Louis Johnson

Portland State University

Follow this and additional works at: https://pdxscholar.library.pdx.edu/open_access_etds

Part of the Art and Design Commons, Art Education Commons, and the Teacher Education and Professional Development Commons

Let us know how access to this document benefits you.

\section{Recommended Citation}

Johnson, Harold Louis, "Increasing Visual Sensitivity in Urban School Students: a Strategy for Involving Students in Aesthetic Concerns" (1973). Dissertations and Theses. Paper 1679.

https://doi.org/10.15760/etd.1677

This Thesis is brought to you for free and open access. It has been accepted for inclusion in Dissertations and Theses by an authorized administrator of PDXScholar. Please contact us if we can make this document more accessible: pdxscholar@pdx.edu. 
AN ABSTRACT OF THE THESIS OF Harold Louis Johnson for the Master of Arts in Teaching presented August 9, 1973.

Title: Increasing Visual Sensitivity in Urban School Students: A Strategy for Involving Students in Aesthetic Concerns.

APPROVBD BY MEMBERS OF THE THESIS COMMITTEE:

Jamea S. Hibbard, Chairman

Craig G. Cheghire

Leomerd B. Kimbrell

The purpose of this thesis project was to investigate a way of fomenting greater student involvement in visual aesthetic concerns through the teacher taking on a partial role of artist-in-residence in order to give students direct contact with his creative ideas. A group of epproximetely one hundred fifty students at John Adams High School were presented with a week-long display of ebandoned autonobile mufIlere accompanied by drawinge of the mufflere in various media. 
INCREASING VISUAL SENSITIVITY IN

URBAN SCHOOL STUDENTS: A

STRATEGY FOR INVOLVING

STUDENTS IN AESTHETIC

CONCERNS

by

HAROID LOUIS JOHNSON

A thesis submitted in pertial fulfillment of the requirements for the degree of

MASTER OF ARTS

in

TEACHING

Portland State University

1973 
TABIE OP CONTENTS

PAGS

IIST OF PIGURES.......................... Iv

CHAPTER

I INTRODUCTION......................... I

II PROJBCT DESCRIPTION.................... 4

Summery of Student Written Impressions..... 4

Summary of Student Responses to Questions

for Reaction...................... 8

III CONCLUSION........................ 13

BIBLIOGRAPHY.......................... 16

APPENDIX A............................... 17

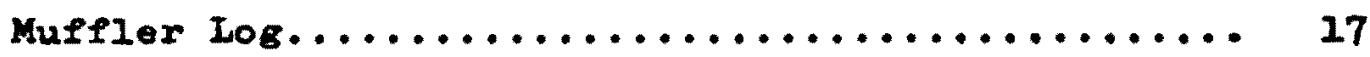

APPENDIX B............................... 22

Drawinge and Printe by Harold Johnson........... 22 
CHAPTER I

INTRODUCTION

Teacher involvement, practical as well as theoretical, in visual aethetic concerns is the basic requirement for auccess in the approach described in this project. For his own srowth as well as that of his students, the teacher ehould be willing to inject himself into the learning procees ab example number one. By dieplaying his own creativity and involvement with aesthetic values, the teacher of art can effectively help students focus on these concerns. The reeulting dialogue can be broadening to student and teacher alike.

The teaching of art necesearily involves demonetration by the teacher of the very values and attitudea that are being encouraged. The willingnese to be "involved," to venture into the unknown to seek the poetic and the unusual, to tolerate ambiguity....1

This approach and particular presentation are founded upon the belief that emphasis upon the aesthetic qualities of experience is an appropriate and meaningful emphasib for otudents today. Its main purpose is to develop in students a critical attitude toward vibual experience. Hopefully, this critical attitude will carry beyond the vieual arts to all

$I_{\text {Hausman, Jerome, "Teacher as Artiot and Artiat ae }}$ Teacher," Art Educetion: Journal of the Nationel Art Bducetion Association, XX, Number 4 (1967), 13-17. 
areas of the etudent's activity so that he will acquire the habit of eeeing his experience in its eesthetic aspect ae well as in other ways. For purposes of this discussion, Kern's description of aesthetic experience will do:

Whenever a person attende to an experience, whether it be Iistening, participation, or watching, he is involved in an aesthetic experience.....More precisely. to attend to an experience implies that there is an interaction between the person and an aesthetic object. The interection is controlled by the sensuous and (when present) representational qualities of the aeathetic object, that is, qualities perceived through the enene, e.8. colors, movement, warmth, etc., and repreaentations, Ideas, and images resulting from the etructurins of these sensuous qualities.2

Such attention to experience is a natural human tendency, but experience shows that it is a tendency which neede continuoue cultivation if it is not to go to seed. Axt, in general, hae been the great inetmuent by which cultivation has taken place. This project is a emall particular example of how growth in appreciation of the aesthetio qualities of experience can be encouraged.

It is hoped that, along with growth in appreciation of the aesthetic qualities of experience, there will be growth in the habit of thinking critically. This is probably the ereatert value to be gained from any educational experience, and it is effectively served by an open, creative experience of art. If the student should develop into a connoiseeur of experience, one who it capable of making judgments for himself,

2Kern, Even J., "A Proper Function for Art Bducetion in the Seventie日," Studies in Art Education, NAEA, a Journal of Iobues and Research in art Education, XII, Number 1 (1970), 7. 
and one who actively seeks to make his environment life-bupporting and attractive, the fruition of critical thinking will have been attained as well as the goal of art education in the schoola. 


\section{CHAPTER II}

\section{PROJECT DESCRIPTION}

The subject matter chosen for this project--abandoned automobile mufflers collected from streets and highways--was selected for its status as a usual and bisarre form of entironmental pollution, and because it relates to an object of endlese fascination to American teenagera: the automobile. The project was installed at John Adams High School in the area occupied by the Quincy School, a general education agency of approximately one hundred fifty students within the high school. Some of the students were presently taking art courses; othere were not. Eighteen drawings were displayed along with twentyfive used mufflers. Bach muffler rested upon a rectangular piece of canvas of appropriate dimensione (Figure I). The drawings occupied a bulletin board area on the north wall of the approximately fify by fifty-foot room (Figure 2). On the floor the mufflers were aligned in rows so that they moved somewhat into the space ubually trafficked by the Quincy population. Studentr moved through and around the exhibit and worked in proximity to it throughout the period of its diepley (May 18, 1973, to May 25, 1973).

\section{SUMMARY OF STUDBNT WRITTEN IMPRESGIONS}

A five-foot etrip of butcher paper was placed on the 


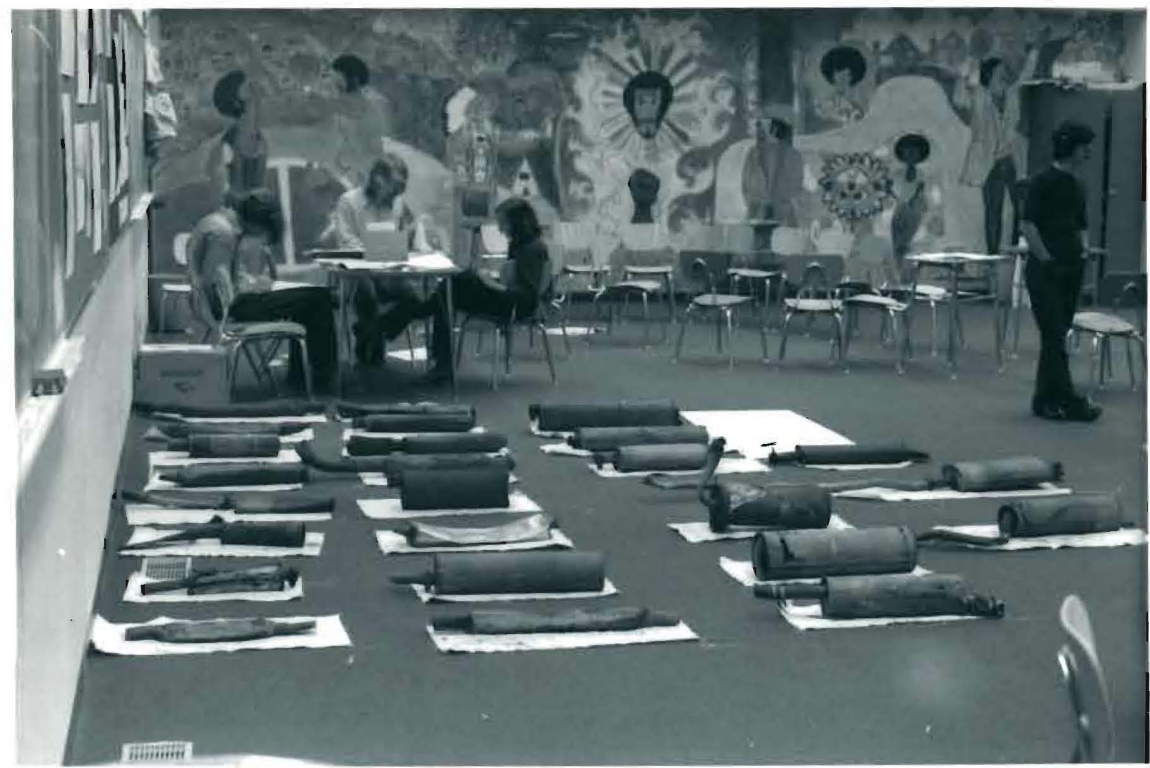

Figure 1. Placement of mufflers upon rectangular pieces of canvas of appropriate dimensions.

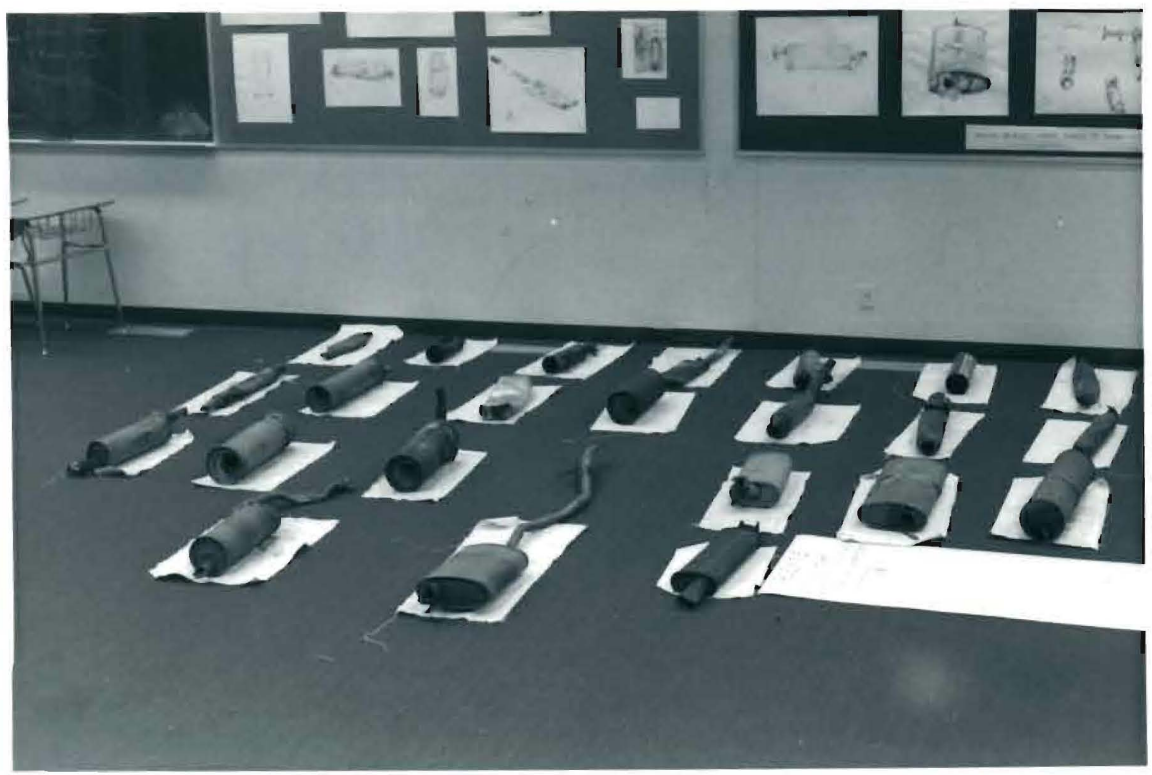

Pigure 2. Section of drawing display on bulletin board. 
floor among the mufflers soliciting on-the-spot comments upon the display (Figure 3). A questionnaire containing six itemo prepared in cooperation with a member of the Adams research Btaff was also available to students who wished to respond more fully. Duxing the week of the display, two discussions were held with Quincy students regarding the nature of the presentation. Numerous other one-to-one discussions were held with curious students during and after the week of the display.

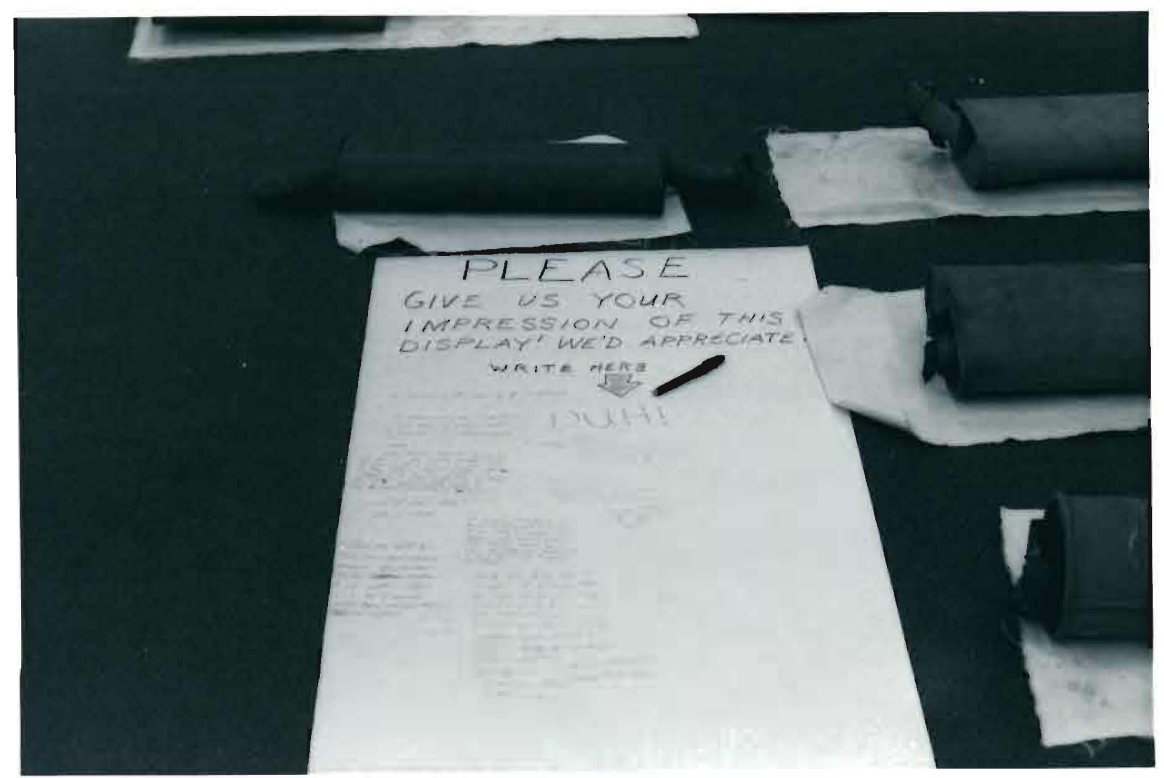

Pigure 3. Pive-foot strip of butcher paper used to record on-the-spot impressions.

Spontaneous written responaes grouped themselves according to those who saw the display as a reaction to environmental pollution and centered their attention on the mufflers, those who reacted to the drawings with little or no mention of the mufflers, and those who were surprised and, in some 
cases, happy to find out what a mufler looked like. Most etudente responded in a straightforward manner; however, a few took the opportunity to exercies their predilectione for humor: "It'Il never fly, Oxville." "Where have all the cere gone?" "Silence, please." "Looks like a job for Midas Mufflera!"

The following comments are characteristlc of those which made the ecologioal connection:

Somehow I feel uncomfortable standing in a display of decaying metal that is presented in such an orderIy way. I feel like throwing them into a disorganIsed pile.

My firet reaction was, "God, these are uely!" Now that I look at these mufflers, I think they are kind of neat. I didn't know there were so many kinda of mufflers. They do bring up some depressing attitudes of the American people--Everyone ahould each own a car, T.V., radio, stereo, boat, etc. Bach of us wasting incredible amounts of energy, materials, and polluting our environment.

These comments proved rich in suggestions for follow-up discuseions with etudents.

Studente did not readily connect the drawinge with the mufflere. Commenta tended to be of the either/or variety-about the mufflers or about the drewings. Comments on the drawings did not show notable range or involvement though expressione about them were erequent: "Good job with the paintinge." "Did you enjoy drawing these ugly critters?" "The real mufflere are ugly but the drawings are good." "Mufflers are a very etrange thing to paint. Good job." The "paintinge" referred to by some studente were actually watercolor drawings. 
A surprising number of students disclosed that this wes their firat experience of recognizing a muffier.

At first I thought it was kind of uely, but I never know what a muffler was before and now I know. I also didn't know there was all different kinds; it's a very good and original collection.

Pirst time I've over seen a muffler. It kind of makes me mad 'cos for every muffler lying around there is a car riding around without it making a hell of a lot of noibe: and pollution:

While this last comment perhaps concludes a bit too much, another thoughtful respondent, reacting to the placement of the dieplay in his classroom, summed up (perhape unwittingly) the besis of the entire production in these words: "This is a thoughtless amendment to our environment."

The above student comments are representative of the more than fifty which were written on the putcher paper provided for immediate impreseions. Students appeared to enjoy recording their critical impressions of the diaplay, and the process contributed to much opening up between etudents and teachers on the subject of art and environmental pollution.

\section{SUMMARY OF STUDENT RESPONSES TO QUESTIONS FOR REACTION}

The questions used to gauge student reaction to the display and to evoke critical responses were designed to be ae unobtmusive as possible while encouraging students to answer as Ireely as possible. Mention of environmental pollution or ecolocy in the questions wes purposely suppreseed. Twentyfour individuals responded to the questions. The six items and a brief description of student reaction to them follows: 
Describe briefly what it is you are (or have been) seeing in this exhibit. Studenta responded uniformly that they saw twenty-five old and dirty mufflers. A few expanded their comments to notice that the mufflers were "laid out in rows," that drawings accompanied the objects, or that the objects each rested on a piece of canvas. Two responses suggested environmental concern: "Pollution by man," said one, and, "I Bee twenty-five unrecycleble mufilers which really bothers me." What do you think, see, or feel as you look at these objects on the floor? This question was intended to develop the direction indicated in item one. To give students the experience of viewing an art dieplay elsewhere than on a wall or pedestal was also an objective embraced by this queation. Perhaps the notion or experience of having ouch objects underfoot accounted for the several responses which expressed some degree of anger: "My mind has to think in terms of ecology and I feel upeet and have a feeling of anger." "Bork: They are ugly! They look like army ante ready for attack!" The theme of militance in the diaplay, characterised by the comment immediately above, was assumed to relate to the kind, number and arrangement of the mufflers. The following response attacked the question more maseively:

I don't think there's anything 'beautiful' about it. I'm amazed at the variety of shapes and colors. The only thing that makes this part of the display appealing is the amount of objects and their layout (and their mere exiatence in this place is a very welcome addition and change). It feels noisy:

The notice here and elsewhere of the issues of scale, exten- 
oion, pattern, ehape, color, and space would seem to support the idea of the eesthetic-educational potential of such a project. One respondent offered the euggestion that the muffler dieplay "would be better if they were not in rowe." What do you think, see, feel, as you look at the dravinge of these objects around the exhibit? As Indicated above, the question was designed to give students maximum letitude In responding. However, as on the sheet for immediate reeponses, the range of comments was not great, with most of them making a more or leee complimentary remark and moving on. Most often the drawings were seen as "nice," apart from the "ugliness" of the mufflers: "The shapes and colors are nice, but the actual objecte...." "I think they are very good drawinge of the very ugly junk." Three of the comments indicated appreciation of the drawings and mufflers together: "The drawings seem to bring out the rusticness of the objects." "Old mufflers have a fair chance of becoming art forms."

The drawinge make me like the objecte; if a piece of junk oan have someone create an intereating picture, I'Il accept it. I can enjoy looking at the drawings for a long time.

One student commented that he did not see why the drawinge were neceesary for the exhibit, implying (perhaps wisely) that the mufflers were enough by themselves.

What kind of person might construct this kind of exhibit with the objects and drewinge thet you see here? Bight otudente answered that they oaw an art or ecological interest, or both, as a basis for the presentation. The question re- 
presente an attempt to lay a foundation for dialogue on the subject of art-awareness beyond classroom activities of paintIng, drawing, weaving, ceramics, etc. Studente did make comments and ask questions about the display until the termination of school for summer vacation.

Have you seen these kinds of objects anywere else? Were? Often? "Junk yards, car shops, streete, under cars. Not often." Four people eaid they had never seen an abandoned muffier before. One expressed eurprise that all of the mufflers could have been found on Portland-area streets. The question was intended to bring the objects closer to the experience of the otudents, and, again hopefully, to help sensitize them to anomalies in their environment. It would be hard to imagine most of the people who experienced the display not more readily than before noticing automobile junk left in the atreets.

If you were asked to do something (anything) with the objecte of this display, or similar objects, where would you so to find them, and what kinds of things might you do with them? Most of the people were stopped by this question as might have been expected since their experience with auch materials was quite limited. Several answered easily that they might collect things from a junkyard and make sculpture or "modern axt." One student who tried hard said, "Well, if you wanted to make some bizarre sculpture, weld them together and send it gift-wrapped to Georgia Pacific to add to their collection." 
To conclude this ourvey of student reactions here is a

brief essay one student wrote in response to the six items:

I see a bunch of junk on the floox but it looks better on the floor than on the street. All of these came off of the cars that drive our atreets and highways. I think the people could of took these to the dump or just put them in the garbage can instead of the streets. All I see on the wall is a bunch of drawings of broken down old mufflers and they are bad drawings of them anyway. I feel they should put a deposit on old mufflers so people don't juat throw then away. I think the person is concerned about the city we live in but is also concerned with old mufflers. Yes I have seen these objects on the streets and on the beck roads and quite often. I would probably go on all the back roads and collect them and once I got them I might recylce them (aic). 
CHAPTER III

\section{CONCLUSION}

Student response to the presentation euggests that this approach has great potential in a number of areas. In giving studente a chance to exprese themelves about the work of the teacher-artiet an open climate was fostered. Students readily received and sought information. Through confrontation with the display, they gained fresh ideas about the oubject matter of art. A natural embelishment to a project of this type, and one which would lend interdisciplinary force to it, would be to have otudents log their findings, collectings, problems, or whatever, when doing their ow projecte. (Seo Appendix A,) The dialogue that ensued as a result of this self-exposure on the teacher's part was rich in opportunities for the development and practice of critical thinking.

Teachers who are willing and able to approach students in this manner from time to time will be giving students an experlence usually reserved for programs where an artiot-inresidence is present. The frequent use of artiste-in-residence in schools, emphasizing the artist as a model for art education, is a recogniged technique for enriching the experience of art etudents. 3 It seems reasonable that where the

3 Art Bducetion: Senior High School, Written by a Task Force of Specialiste in Senior High School Art Iducation. Cheirman: Angela G. Paterakis (Washington D.C., 1972), p. 19. 
artist-teacher can periodically perform the service himsele he should do so. Archibald MecLeish's comment about poote will do as well for artista:

Bvery poet learns, I suppose, whet Virginia Woolf had learned by her middle thirties, that the creativity of othere will release his own, if they are the right 'others' and if he himbelf is right to receive them at the moment when he comes to them. 4

The artiat-teacher who has a relatively intimate knovledge of his otudents has an excellent chance for being the "right other" through the judicious dieplay of his oreative output. That studente will respond poeitively to ouch an approach bas been augeested by the present study.

While the project centered upon sensory awareness, visual expansion, a bignificant amount of factual information was exchanged, from discovering the nature of mufflers to learning that art does not have to deal with the sweet and the beautiful. Readiness to build upon these information opportunities could add depth to a similar project.

Poseibilities for dielogue with etudents, based on the display, appear to be manifold. Such an event becomes a longrenge point of identification for atudenta. Teachers in the Quincy School reported that questions and discuseion of the muffler dieplay were continuous. It seems reasonable to assume thet studente could be similarly involved in any creative profect stemming from an artist-teacher's contemplation of life.

4Macteiah, Archibald, Art Education and the Creative Procese. Published for the Committes on Art Bducation by the MuBeum of Modorn Art (New York, 1953), p. 5. 
During the course of the display, otudents readily esked questions about its creation and possible meaning. The disposition to attempt reasoned judgments about their experience of the project hinted at the promise of this approach as a way of involving students in critical thought about aeethetio experierce. An ideal outcome of this project would have the otudent growing ever more skillful and independent in the making of aesthetic judgments and finding a need to ourround himself with sources of eesthetic experience. Ultimately this attitude would express itself as concern for aesthetic valuea in the community. A few students in the responding eroup aev to be near this point already. Many more could be brought to the beginning of such awarenese through experiences which call upon more of the total person--from teacher as well as atudent. 
Art Bducation: Senior High School, Written by a Task Force of Specialista in Sentor High School Art Education. Task Force Chairman: Angela D. Paterakis. Weshington, D.C.: 1972

Hausman, Jerome 1967. "Teacher as Artist and Artiat as Teachor," Art Bducation: Journal of the National Art Bducation Aasociation, XX, Number 4 .

Kern, Evan J. 1970 "A Proper Function for Art Bducation in the Seventies," Studies in Art Educetion, NABA, a Journel of Issues and Research in Art Education. XII, Number I.

Lowenfeld, Victor, and Brittain, W. Lambert, Creative and Mentel Growth. New York: 1964.

Macleish, Archibald, Art Education and the Creative Procese, Published for the Committee on Art Educetion by the Museum of Modern Art. New York: 1954. 
APPENDIX A

MUFFIER IOG

Number 1, May 13, 1972

The defective muffler from my own 1963 Rambler etarted it. The mechanic warned me in oblique but no uncertein terme of the hazards of driving to Los Angeles with a muffler in auch condition. Doubtful at firet, I later noticed that eome arees in the muffler had the consiatency of oatmeal.

Number 2, Sept. 3, 1972

This one was found on the side of St. Helens Rond near the city limits sign at 8,00 a.m. I soon discovered thet on any day I could drive randomly for two hours or so and find at least three or four abandoned mufflere. Early morning is best for colleoting. As I pulled up to retrieve Number Two, a big long-eard sand-colored dog came loping up, barking, to let me know that I was invading his territory. He kept a fair distance, but I felt better once I got the muffior in my hands.

Number 3, Sept. 3, 1972

Coming in the First Avenue cutoff to Corbett Street, I found the first of three mufflers that were located near this epot.

Number 4 , Sept. 3, 1972

Four was found lying in back of a house at Southweat Curry and Water Streets. 
Number 5, Oct. 24,1972

This one was aprawled across the parking etrip on Southwest First and draped into the gutter. The goung man at the house said that his brother had abandoned it there and that it was free for the taking, though he couldn't imagine....

Number 6, Oct. 14,1972

At $6: 30$ a.m. Number Six was picked up on Southeast Bighty-Second Avenue.

Number 7, Oct. 14,1972

Roadside debris on Northeart Columbia Boulevard yielded Number Seven.

Number 8, Oct. 24,1972

Not long after the previous one. I found thie mufeler in the middle of North Columbia Boulevard. A flock of etarlinge rose in a cloud from a roadiide field as I ploked up Number E1ght.

Numbers 2 and 10, Oct. 14, 1972

Coming off St. Helens Roed, I found these two abandoned in the weeds beside the Montgomery Ward employees parking lot. In a little over two hours this morning I found six mufflers. It began to seem akin to fishing.

Number 21, Oct. 21, 1972

This one had been abandoned on the Washington alde of the Columbla River just west of Stevenson. 
Number 12, Nov. 30, 1972

Twelve was perched on the curb of an underpase exiting the west end of the Roes Island Bridge. Dangerous retrievel.

Number 13, Dec. 2, 1972

Thlrteen was picked up on Barbur Boulevard on my return Irom a visit to Fred Meyer's.

Number 14, Dec. 19, 1972

As I returned home from work, I discovered this muffler on I-5 near the Weidler Street exit.

Number 15, Dec. 22, 1972

Fifteen was lying in the gutter on Northeast Fifteenth near Killingoworth Street. People are atarting to tell we about mufflers they have passed lying in the streets.

Number 16, Dec. 26,1972

This one lay neer the Barbur Boulevard exit to Front Arenue. On another occasion, a big one got away at this spot because the traffic was too fierce for atopping.

Number 17, Feb. 17,1973

After watching it for four daya on my way to work, I was able to retrieve Seventeen early on this Saturday morning et the entrance to $80 \mathrm{~N}$. I had misgivings. A pereon had been killed there (changing a tire or some such thing) only recentIy. 
Number 18, Feb, 17,1973

I was back on Southeast Bighty-Second again.

Number 19, Fob. 17, 1973

Near the ame ppot as Number Twelve. I had earlier considered patroling the same area each time I went out on a eearch.

Number 20, March 3,1973

On the way to a friend's house for breakfaet, we found Number Twenty on Barbur Boulevard just north of Tigard.

Number 21, Merch 13,1973

Twenty-one was lying along I-5 south of the Alberte

Street entrance as I came from work.

Number 22, March 24, 1973

This rusty epecimen was peeping up from the side of the Columbia River Highway near Hood RIver.

Number 23, March 27, 1973

Barbur Boulevard again, just south of Lair Hill Park and practically on my doorstep, was where I found this mufeler. I had been wondering when I would find one this close to home.

Number 24, April 18, 1973

This was found on the Bertha Beaverton Highway while traveling out to the Xerox headquarters for Business-Bducetion Day. 
Number 25, April 29, 1973

Iwenty-five was found on HIghway $8 O N$ on the way to work, just short of the Thirty-third Avenue exit. It was a little bit exciting with all the morning rush-hour traffic nooming by. 


\section{APPENDIX B}

DRAWINGS AND PRINTS BY HAROID JOHNSON

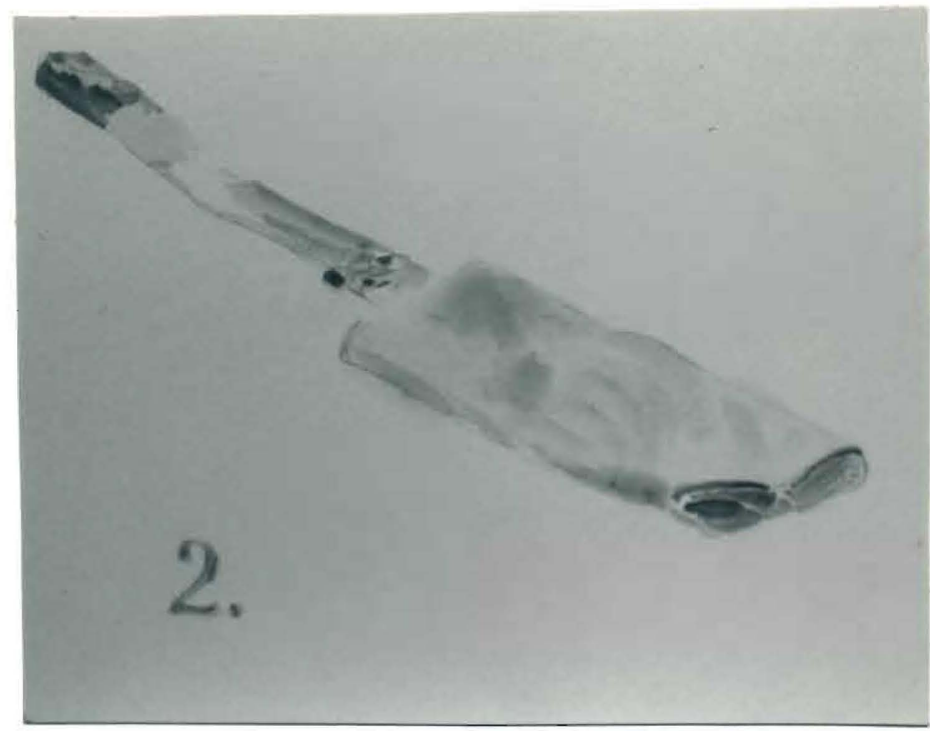

Number 2, Watercolor. 16" by $18^{\text {" }}$

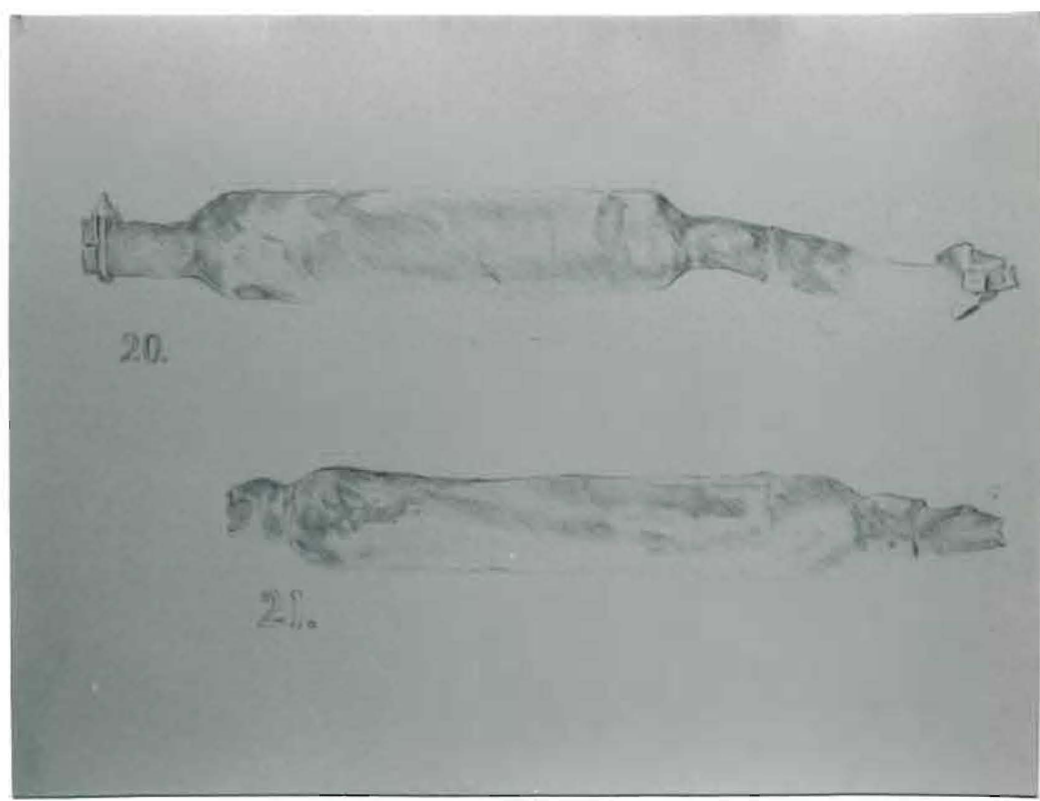

$20 \& 21$, Conte Crayon. 19" by 24" 


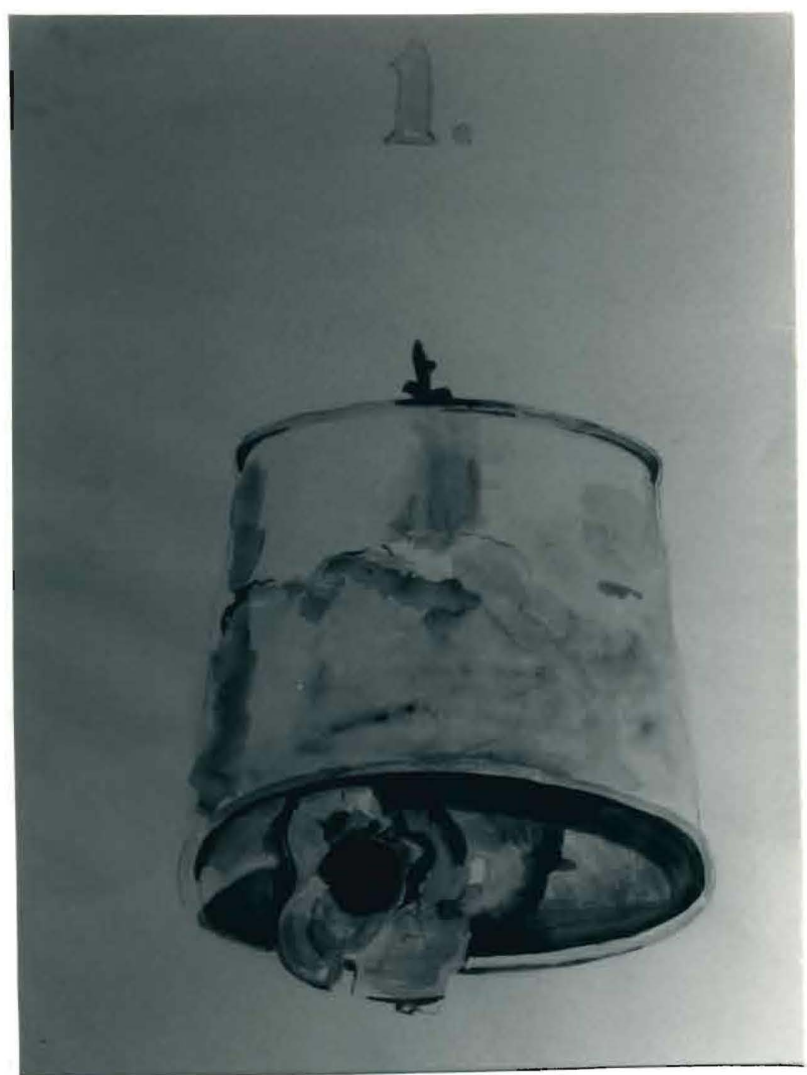

Number I. Watercolor. 19" by $27 \frac{1}{2}$ "

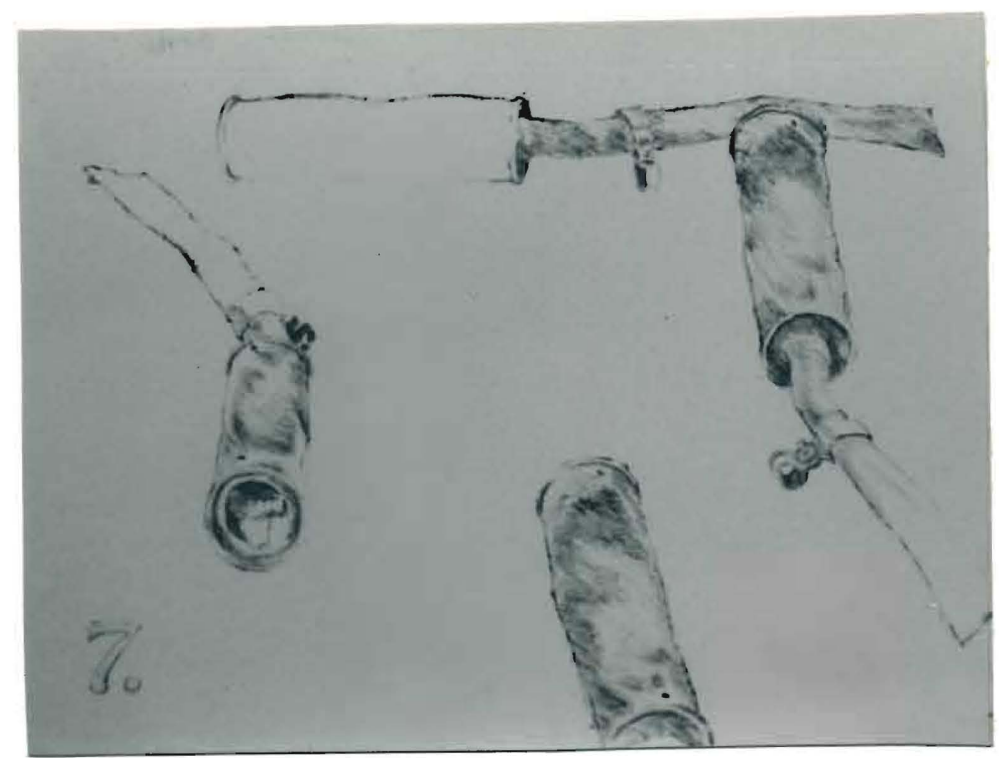

Number 7. Oil on Paper. 19" by 24" 


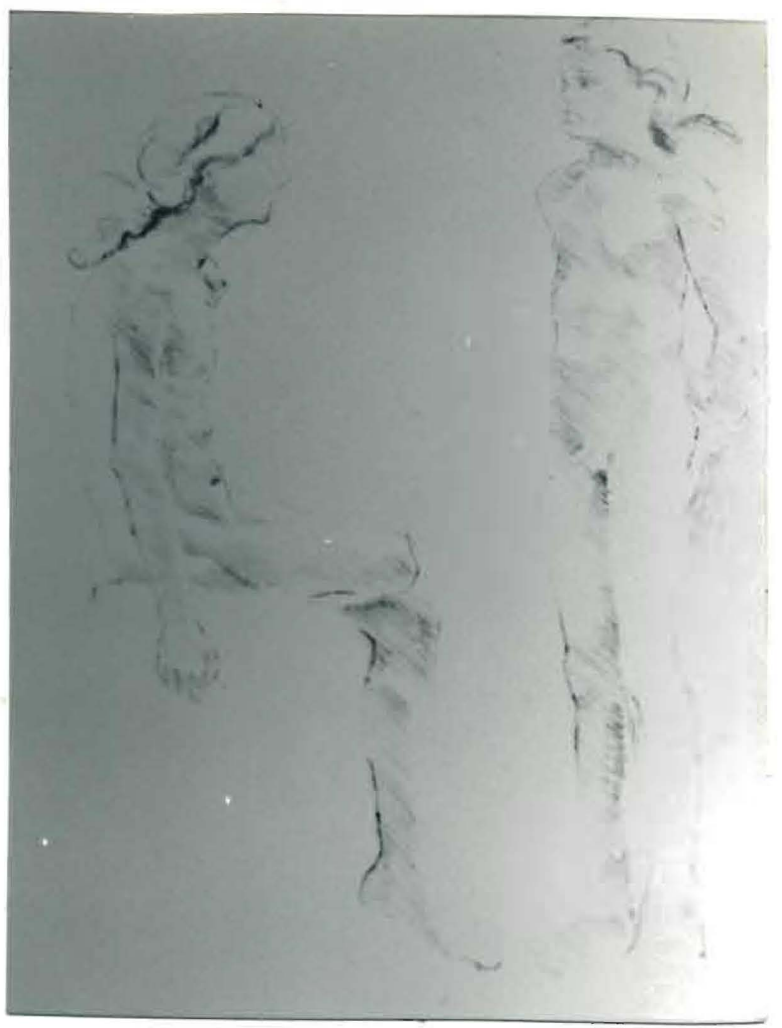

Figure Study, Oil on Paper. 19" by 24" 


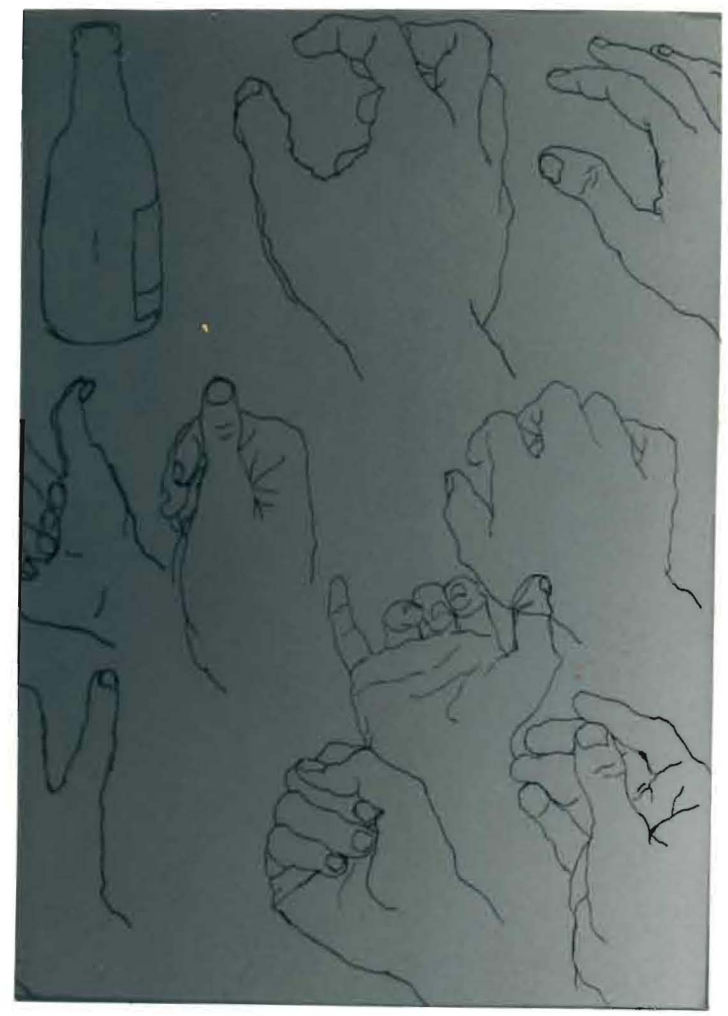

Hand Study, Ink. $10 \frac{1}{2} "$ by $13 \frac{3}{4}$ 


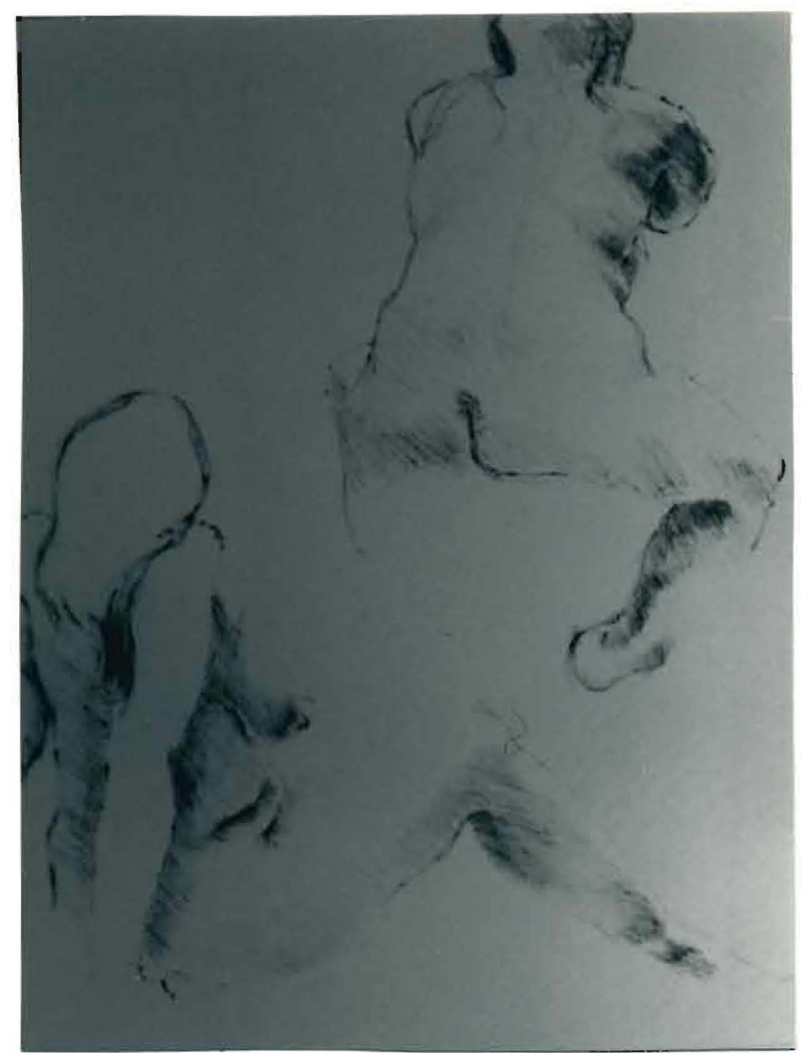

Figure, Oil on Paper. 19" by $24^{\prime \prime}$ 


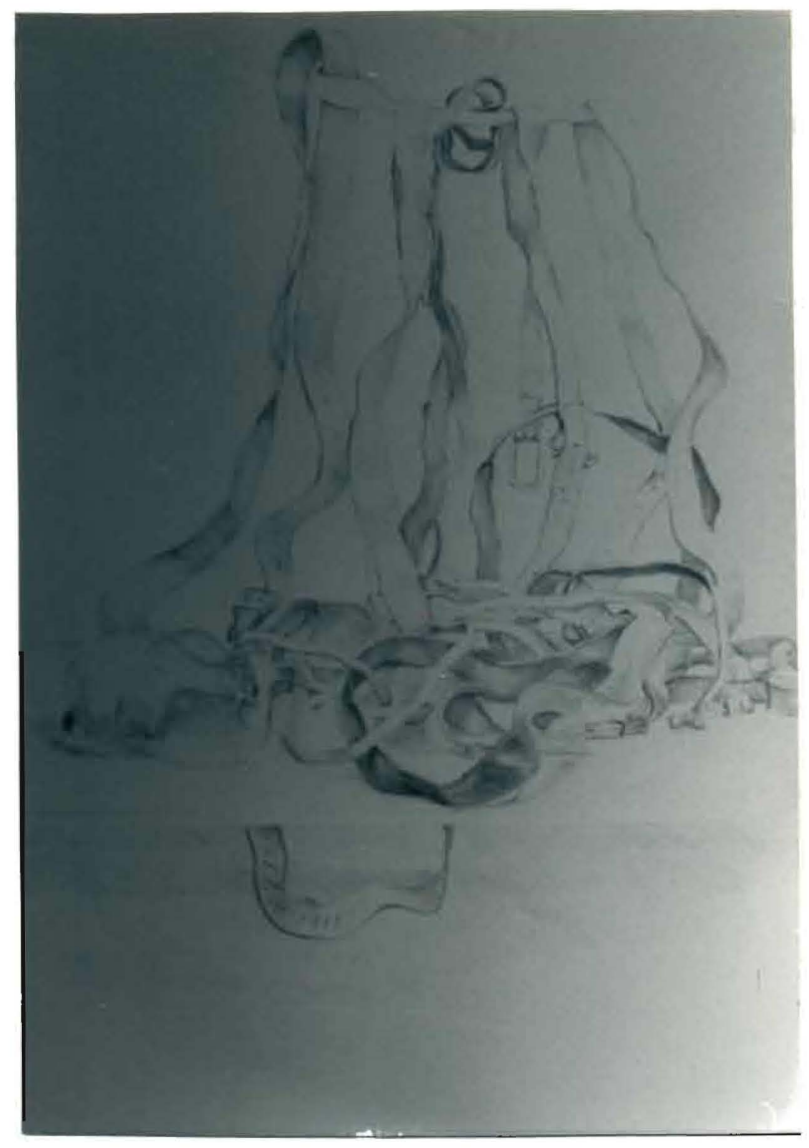

Horse Harnesses, Pencil. 20" by $28^{\text {n }}$ 


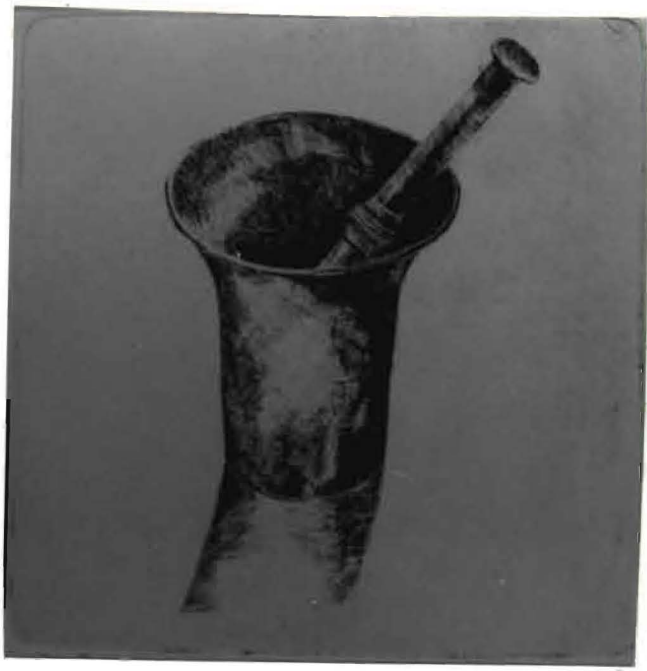

Mortar and Pestle, Etching . $57 / 8^{\prime \prime}$ by $53 / 4^{\prime \prime}$

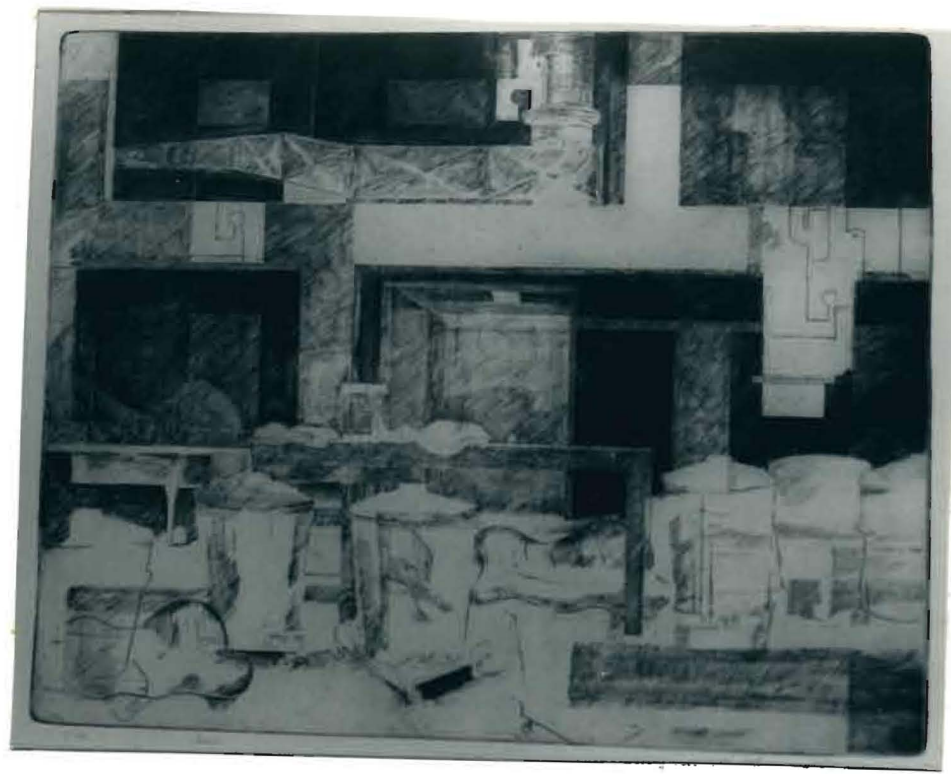

Crux, Etching. $133 / 4^{\prime \prime}$ by $17^{\prime \prime}$ 